\title{
Impact of Global Economic Factors on FDI Flows in to India-An Empirical Research
}

\author{
R S Ch Murthy Chodisetty, L Deepshika Reddy
}

\begin{abstract}
Global investments are engaging a crucial role in the growth of Indian economy better than other nation's economy in the present. More nations are providing more savings and attracting global investments. The requirement of global direct investments are deepening

Inflows rate in any nations in the world. Global direct investments are specified a route between global inflows and savings in the country. In the process of Global economic development global investments helped to cover to Indian savings and provide entry routes in to India for development growth of Indian economy. This paper mainly focus on crucial of global economic factors on Indian FDI flows

Key words: Global Economic Factors, FDI flows, FII flows, flow of investment
\end{abstract}

JEL Codes: F-21, E-22, O-24, F-35.

\section{INTRODUCTION}

Global investments are playing a most important role in Indian economic growth.The rapid growth of foreign direct investment by various multinational companies is attracting more or highest FDI flows in to India since 1990-1991. The government of India is introduced in the year of 1990-1991 by the concept of LPG (Liberalizations, Privatization and Globalization.)

The economic growth of India is based on the global economic factors are playing an important role in economic development in India.

\section{REVIEW OF LITERATURE:}

1. Dunning (1998)1: -This study of research analyzes the interface between trade, foreign direct investments flow and globalization patterns. The findings of the study focused on competitiveness in the impact of globalization of various countries and the differed role of Global investments in the economy and how the state and government economic and global economic factors and policies increasingly suppressed with each other.

2. Banga, (2003)2:-The study highlighted foreign direct investment inflows of fifteen developing countries of south, east and south-east Asia then undertaken for foreign direct investments from developed and developing countries, the results were depicted to removal of restrictions attracts aggregate foreign direct investments but not the fiscal incentives. But it is foreign direct investment inflows impact the

Revised Manuscript Received on April 12, 2019.

R S Ch Murthy Chodisetty,Assistant Professor, School of Management Studies, SNIST, Hyderabad,Telangana, India.. (E-mail: b4u@gmail.com)

L Deepshika Reddy, Student, B.Tech -III Year, Department of ECE, SNIST, Hyd Telangana, India. (E-mail: ldeepshikareddy@gmail.com) developing countries on basis of institutional factors of the government.

3. Jeevan Kumar and Susheela Subrahmanyam (2012)3: - The paper deals with the strategies and action plans for sustainable development of Karnataka by 2025 . The book makes a pre-assumption that sustainable development is the path that Karnataka has to adopt in order ensure development by 2025 . Hence, the book needs to be located in the discourse on 'sustainable development'. Under an enlightened leadership, the state is shifting to e-governance, building public-private partnerships in key sectors.

4. Mirza, (1998)4: - The research paper titled "Fixed Costs and FDI, The Conflicting Effects of Productivity Shocks" emphasized the two fold nature of investment decisions. For this decision, the setup costs played on role. But in the presence of fixed setup costs, the profits that are generated when the firm carried out the amount of investment called for. By marginal productivity conditions might be negative. Thus study concluded that the investment decision of the firm was two folded whether to invest at all and if so how much to invest

\section{II.1. Objective of the study:}

1. To know the flow of Global investments in india

2. To analyze the select global economic factors which are influencing the FDI flows into India.

\section{II.2Hypothesis of the study:}

1. H0: There is no impact of global economic factors on FDI flows into India.

2. H1: There is an impact of global economic factors on FDI flows into India.

\section{II.3Scope of the study:}

The present study has been emphasized from the period of 2003-04 to 2016-17. The study considered five global economic factors, namely as follows:

(R) Dollar Index

(R) Baltic Dry Index

(B) Global Inflation

(B) Global Imports

® Global Exports

\section{RESEARCH METHODOLOGY \& RESULTS:}

1. Our empirical analysis is predicated on a Panel data of FDI flows from various countries over the period 2003-04 to 2016-17. The variable, FDI flows, is

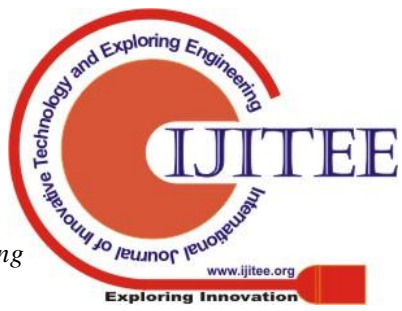


captured by the annual data for the net FDI inflows as a \% of GDP from World Development Indicators. During this study, our baseline model is as follows:

2. We are using a few statistics techniques.

\section{Stationary (ADF Model):}

On the time series data Johansen co-integration test has been applied to know co-integration between the Global economic factor with Indian FDI flows by using Trace and Eigen test has been applied.

ARDL model: The Auto Regression Distribution Lagmodel have been applied on the time seriesto confirm the long or short run association between the global economic factor on Indian Flows.

Bound test: Bound test have been applied on the time series data to identify long or short run association between the global economic factor on Indian flows by using Fstatistic

Data analysis and Interpretation (objective wise):

1. To know the flow of Global investments in india

FDI and Economic Growth in India: The Conflicting Effects of Productivity Shocks" emphasized the two fold nature of investment decisions. For this decision, the setup costs played on role. But in the presence of fixed setup costs, the profits that are generated when the firm carried out the amount of investment called for. By marginal productivity conditions might be negative. Thus study concluded that the investment decision of the firm was two folded whether to invest at all and if so how much to invest

2. To analyze the select global economic factors which are influencing the FDI flows into India.

\begin{tabular}{|l|l|l|l|}
\hline HO: & Obs & F-Statistic & Prob. \\
\hline DDollarIndex does not Granger Cause DIndianFDI & 21 & 2.02195 & 0.1649 \\
\hline DIndianFDI does not Granger Cause DDollarIndex & & 0.2286 & 0.7982 \\
\hline
\end{tabular}

The above table indicates the granger causality test result of $\mathrm{P}$ value is observed to be non-significant i.e., $0.4501>0.05$. Hence, the null hypothesis has been rejected and accepted the alternative hypothesis.The Granger causality test indicates that the unidirectional causality is there between the global Dollar Index and the Indian FDI; the Indian FDI and the Dollar Index p value is stated to be non-significant. Hence null hypothesis will be accepted that the Indian FDI will not granger cause Dollar index

\section{LAG SELECTION}

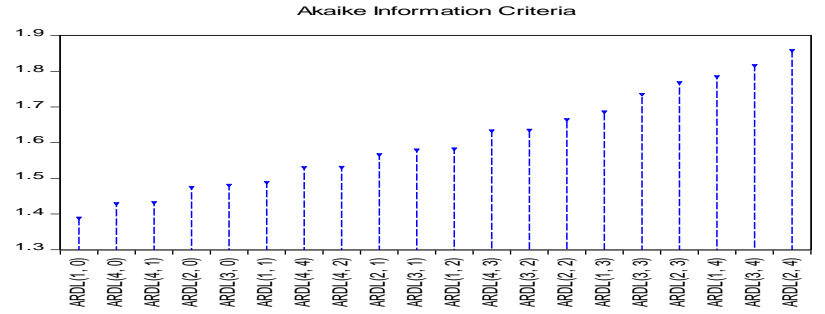

The above AIC(Akaike information criterion) graph shows that Independent variable (dollar index) select lag2 and dependent variable (FDI) seem to be selecting lag4 which indicates the model is fit for order selection of $(2,4)$ lag. Hence conclude that $(2,4)$ is selected to construct the ARDL model .

ARDL model state that the p-value for the Independent variable ( Dollar Index) seems to be significant at $5 \%$ level. It is observed that the most of the coefficient value are having positive influence on FDI flows. Further, Rsquare and F-statistic are observed to be strongwhich signifies that goodness of model. Prob (F-statistic) is less than 0.05 that means $\mathrm{HO}$ has been Rejected and Alternative Hypothesis has been Accepted i.e., there is an Long run Association between Dollar Index on FDI flows.

ARDL Bounds Test \& Results

\begin{tabular}{|c|c|c|c|c|}
\hline \multicolumn{5}{|c|}{ Consolidated ARDL Bounds Test } \\
\hline \multicolumn{5}{|c|}{ Null Hypothesis: No long-run association exist } \\
\hline Independent Variable & Test Statistic & Value & I0 Bound & I1 Bound \\
\hline \begin{tabular}{|l|} 
Dollar Index \\
\end{tabular} & F-statistic & 5.894946 & 3.62 & 4.16 \\
\hline Baltic Dry Index & F-statistic & 0.456838 & 3.62 & 4.16 \\
\hline Global Inflation & F-statistic & 0.565013 & 3.62 & 4.16 \\
\hline Global Imports & F-statistic & 2.729519 & 3.62 & 4.16 \\
\hline Global exports & F-statistic & 3.514092 & 3.62 & 4.16 \\
\hline
\end{tabular}

The Consolidated ARDL bound test depicts the long or short run association between Global economic factors on FDI flows. Results state that Dollar Index is lies Above the Upper bound criterion which signify Dollar Index is having Long run association on Indian FDI flows.
Remaining Global economic factor are seems to having Short run association because the F-statistic value are observed ranging below lower bound i.e., < 3.62. Hence concluded that BDI, Global Inflation, Export and Imports are having short run association on FDI flows 


\begin{tabular}{|l|l|l|l|}
\hline HO & Obs & F-Statistic & Prob. \\
\hline DBDI does not Granger Cause DIndianFDI & 21 & 2.4123 & 0.1214 \\
\hline DIndianFDI does not Granger Cause DBDI & & 0.56283 & 0.5805 \\
\hline
\end{tabular}

The above table indicates the granger causality test result of $\mathrm{P}$ value is observed to be non-significant i.e., $0.4501>0.05$. Hence, the null hypothesis has been rejected and accepted the alternative hypothesis. The Granger causality test indicates that the unidirectional causality is there between the Baltic Dry Index and the Indian FDI; the Indian FDI and the Baltic Dry Index p value is stated to be non-significant. Hence null hypothesis will be accepted that the Indian FDI will not granger cause Baltic Dry Index.

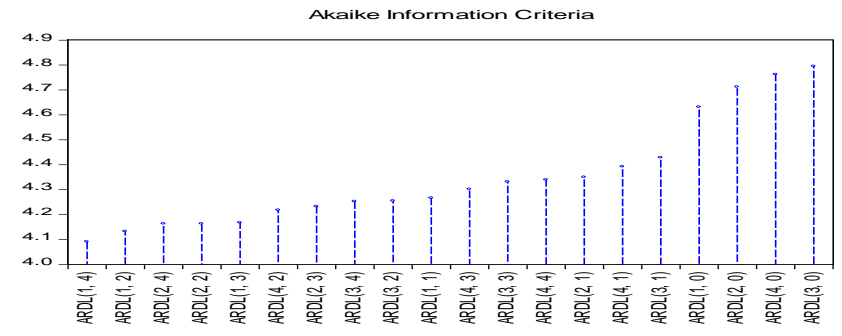

The above AIC(Akaike information criterion) graph shows that Independent variable (BDL) select lag3 and dependent variable (FDI) seem to be selecting lag0 which indicates the model is fit for order selection of $(3,0)$ lag. Hence conclude that $(3,0)$ is selected to construct the ARDL model

\begin{tabular}{|c|c|c|c|c|}
\hline \multicolumn{4}{|c|}{ ARDL Co integrating And Long Run Form } & \\
\hline \multicolumn{4}{|c|}{ Original dep. variable: GLOBALFDI } & \\
\hline \multicolumn{3}{|c|}{ Selected Model: ARDL $(3,0)$} & & \\
\hline \multicolumn{2}{|c|}{ Sample: 124} & & & \\
\hline \multicolumn{3}{|l|}{ Included observations: 21} & & \\
\hline \multicolumn{5}{|c|}{ Co integrating Form } \\
\hline Variable & Coefficient & Std. Error & t-Statistic & Prob. \\
\hline D(GLOBALFDI(-1)) & -0.162649 & 0.170736 & -0.952637 & 0.3549 \\
\hline D(GLOBALFDI(-2)) & -0.119998 & 0.171042 & -0.701574 & 0.4930 \\
\hline $\mathrm{D}(\mathrm{BDI})$ & 0.485259 & 0.118771 & 4.085679 & 0.0009 \\
\hline CointEq(-1) & -0.146399 & 0.122587 & -1.194245 & 0.2498 \\
\hline \multicolumn{5}{|c|}{ Cointeq $=$ GLOBALFDI $-(0.8316 *$ BDI +0.2217$)$} \\
\hline \multicolumn{5}{|c|}{$\begin{array}{ll}\text { Long Run Coefficients } \\
\end{array}$} \\
\hline Variable & Coefficient & Std. Error & t-Statistic & Prob. \\
\hline BDI & 0.831559 & 0.424340 & 1.959651 & 0.0677 \\
\hline $\mathrm{C}$ & 0.221717 & 2.616840 & 0.084727 & 0.9335 \\
\hline
\end{tabular}

The above table contains ARDL and its coefficient value, $\mathrm{T}$-statistic and standard errors are significant at $5 \%$ level .Results reveals that Baltic dry index and FDi are in logarithms and having one cointegrating error. Coefficient estimate value depicts that 1 unit increase of the Baltic dry index will leads to $8.3 \%$ increase in FDI flows.P-value for the Baltic dry index to FDI seems to be non-significant at 5\% level which indicates the null hypothesis has been accepted i.e., there is no long run association of Baltic dry index upon FDI.

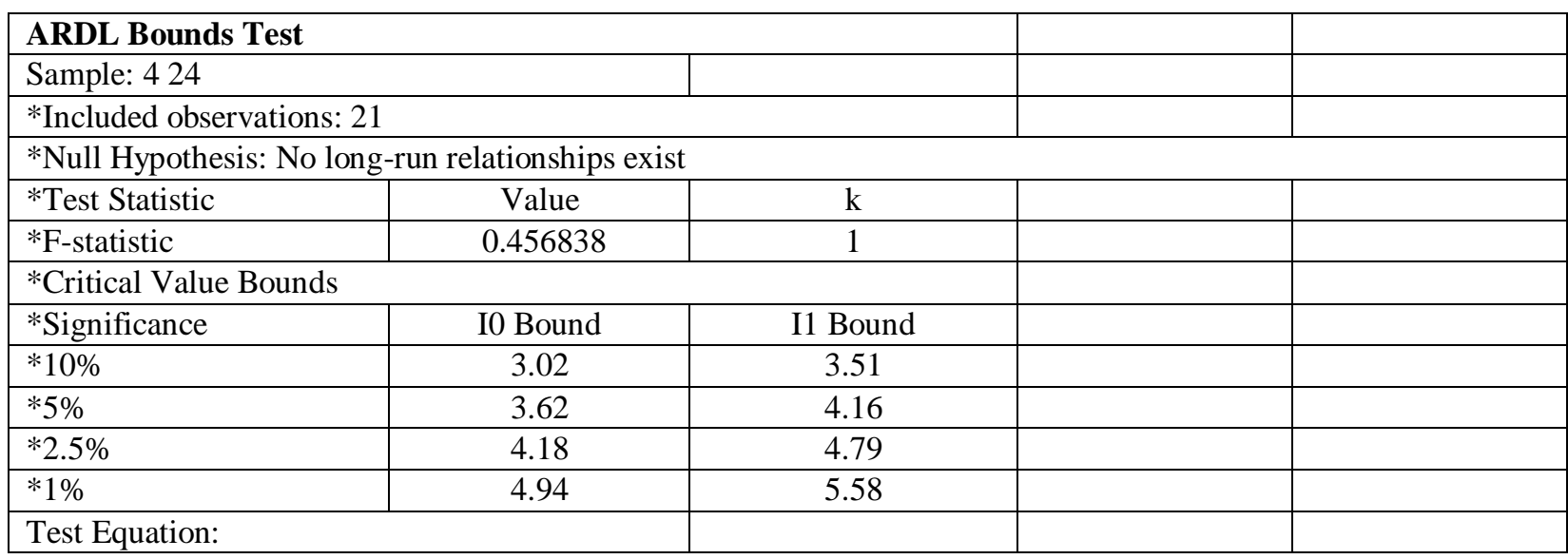




\begin{tabular}{|c|c|c|c|c|}
\hline \multicolumn{3}{|c|}{ Dependent Variable: D(GLOBALFDI) } & & \\
\hline \multicolumn{3}{|c|}{ Method: Least Squares } & & \\
\hline \multicolumn{3}{|l|}{ Sample: 424} & & \\
\hline \multicolumn{3}{|l|}{ Included observations: 21} & & \\
\hline Variable & Coefficient & Std. Error & t-Statistic & Prob. \\
\hline D(GLOBALFDI(-1)) & -0.084514 & 0.260904 & -0.323926 & 0.7502 \\
\hline D(GLOBALFDI(-2)) & 0.008541 & 0.261568 & 0.032655 & 0.9744 \\
\hline $\mathrm{C}$ & 0.247432 & 0.996365 & 0.248335 & 0.8070 \\
\hline BDI(-1) & -0.026149 & 0.151182 & -0.172961 & 0.8649 \\
\hline GLOBALFDI(-1) & -0.127381 & 0.219181 & -0.581168 & 0.5692 \\
\hline The R-squared & 0.081006 & \multicolumn{2}{|l|}{ *Mean dependent var } & -0.395574 \\
\hline The Adjusted R-squared & -0.148743 & \multicolumn{2}{|l|}{ *S.D. dependent var } & 2.495577 \\
\hline The S.E. of regression & 2.674745 & \multicolumn{2}{|l|}{ *Akaike info criterion } & 5.009842 \\
\hline The Sum squared resid & 114.4682 & \multicolumn{2}{|l|}{ *Schwarz criterion } & 5.258538 \\
\hline The Log likelihood & -47.60334 & \multicolumn{2}{|l|}{ *Hannan-Quinn criter. } & 5.063815 \\
\hline The F-statistic & 0.352584 & \multirow{2}{*}{\multicolumn{2}{|c|}{ *Durbin-Watson stat }} & 1.990236 \\
\hline The Prob(F-statistic) & 0.838440 & & & \\
\hline
\end{tabular}

The table depicts the upper bound I (1) and is falls below the 4.16 of the F-test critical value at 5\% significance level and therefore we accept the null hypothesis. The result concludes there is a short association between FDI and Baltic dry index.

The Max-eigenvalue test results have been considered in order to confirm the johansencointegration trace test.
The Max-eigenvalue test also shows one Co integration equation at 5\% level. Therefore, these two tests are stating that Co integration exists between the Indian FDI and the global economic factor - Global Inflation for the 14 years period

\begin{tabular}{|l|l|l|l|}
\hline Null Hypothesis: & Obs & F-Statistic & Prob. \\
\hline Global Inflation does not Granger Cause DIndianFDI & 11 & 2.44512 & 0.1672 \\
\hline DIndianFDI does not Granger Cause Global Inflation & & 0.87098 & 0.4655 \\
\hline
\end{tabular}

The above table indicates the granger causality test result of $\mathrm{P}$ value is observed to be non-significant i.e., $0.4501>0.05$. Hence, the null hypothesis has been rejected and accepted the alternative hypothesis. The Granger causality test indicates that the unidirectional causality is there between the global Inflation and the Indian FDI; but the Indian FDI and the Global Inflation $p$ value is stated to be non-significant. Hence null hypothesis will be accepted that the Indian FDI will not granger cause Global Inflation

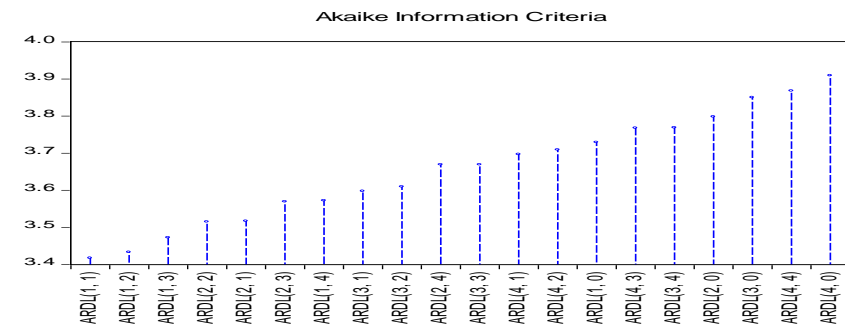

The above AIC(Akaike information criterion) graph shows that Independent variable (global inflation) select lag4 and dependent variable (FDI) seem to be selecting lag0 which indicates the model is fit for order selection of $4,0)$ lag. Hence conclude that $(4,0)$ is selected to construct the ARDL model

\begin{tabular}{|l|c|c|c|}
\hline Null Hypothesis: & Obs & F-Statistic & Prob. \\
\hline DDGlobalImports does not Granger Cause DIndianFDI & 20 & 4.10604 & 0.5378 \\
\hline DIndianFDI does not Granger Cause DDGlobalImports & & 1.72284 & 0.2121 \\
\hline
\end{tabular}

The above table indicates the granger causality test result of $\mathrm{P}$ value is observed to be non-significant i.e., $0.4501>0.05$. Hence, the null hypothesis has been rejected and accepted the alternative hypothesis. The Granger causality test indicates that the unidirectional causality is there between the global Imports and the Indian FDI; the Indian FDI and the Global Imports $\mathrm{p}$ value is stated to be non-significant. Hence null hypothesis will be accepted that the Indian FDI will not granger cause Global Imports.

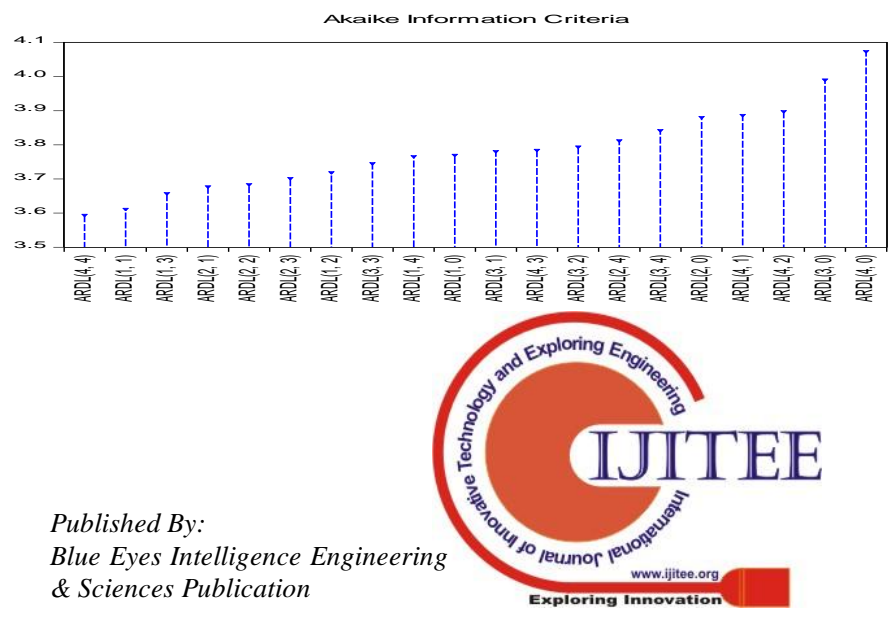


The above AIC(Akaike information criterion) graph shows that Independent variable (global imports) select lag4 and dependent variable (FDI) seem to be selecting $\operatorname{lag} 0$ which indicates the model is fit for order selection of $(4,0)$ lag. Hence conclude that $(4,0)$ is selected to construct the ARDL model

\begin{tabular}{|l|c|c|c|}
\hline Null Hypothesis: & Obs & F-Statistic & Prob. \\
\hline DGlobalExport does not Granger Cause DIndian FDI & 21 & 0.83947 & 0.4501 \\
\hline DIndian FDI does not Granger Cause DGlobalExport & & 1.11114 & 0.3533 \\
\hline
\end{tabular}

The above table indicates the granger causality test result of $\mathrm{P}$ value is observed to be non-significant i.e., $0.4501>0.05$. Hence, the null hypothesis has been rejected and accepted the alternative hypothesis.The Granger causality test indicates that the unidirectional causality is there between the global exports and the Indian FDI; the Indian FDI and the Global exports $p$ value is stated to be non-significant. Hence null hypothesis will be accepted that the Indian FDI will not granger cause Global Exports.

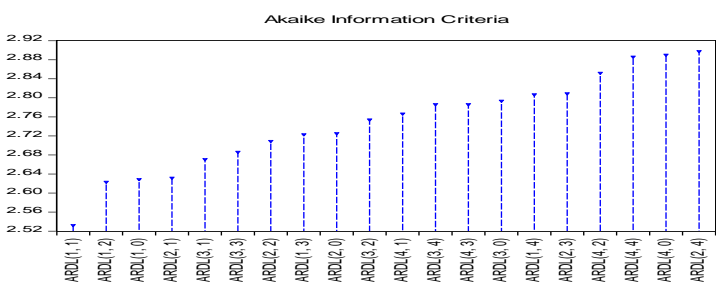

The above AIC(Akaike information criterion) graph shows that Independent variable (global exports) select lag2 and dependent variable (FDI) seem to be selecting lag4 which indicates the model is fit for order selection of $(2,4)$ lag. Hence conclude that $(2,4)$ is selected to construct the ARDL model.

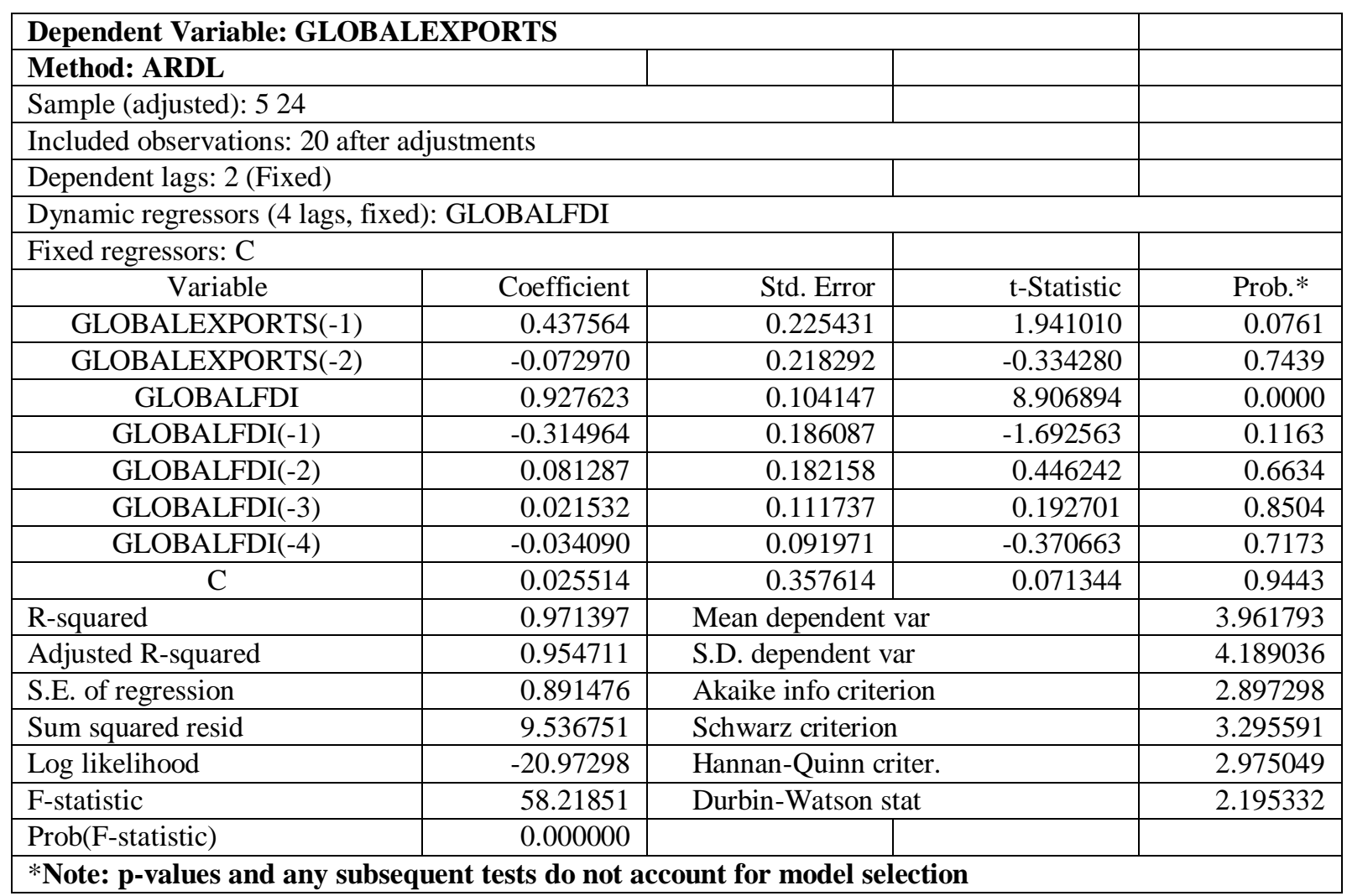

\section{CONCLUSION OF THE STUDY:}

The study concludes the titled "Impact of Global Economic factors on the FDI flows with reference to the BRICs has been done based on the secondary data from the period of 2002 to 2017 . The study result indicates that FDI has got positively influenced by the institutional factors. The regulatory Quality influence has not been found on Russian country FDI.

The India and China institutional factors are having the stronger influence on the FDI flows. The South African FDI flows are highly influenced by the Quality of public services. Hence, there is further scope of research to do in this area by considering the external factors influence on the Indian fdi flows.

\section{REFERENCES}

1. Abdul Aziz(2015)Industrialisation:Socio-Economic Externalities and state policy, Concept Publishing Company, New Delhi, 1997 Vol no 15, Issue 4, Pg.no 58-63.

Published By: 
2. Mohan Guru Swamy Sharma (2016) Mohan Guru Swamy Sharma (2005) Foreign Direct Investment in India's Retail Sector; New Delhi.

3. Bary Rose Worth, Avirmons (2016) "Sources of Growth in the Indian Economy" NBER working paper No. 12901. National Bureau of Economic Research, Cambridge.

4. Rao and Singh (2017): - Towards more Effective Movement, Macmillan, Delhi, 2003. 